Original Research Paper

\title{
Optimization of Rumen Bioprocess through the Addition of Phosphorus and Sulfur Minerals on Ammoniated Palm Leaves and Fronds (Elaeis Guineensis Jacq.)
}

\author{
${ }^{1}$ Suyitman, ${ }^{1}$ Lili Warly, ${ }^{2}$ James Hellyward and ${ }^{1}$ Roni Pazla \\ ${ }^{1}$ Department of Nutrition Science and Feed Technology, Faculty of Animal Husbandry, Universitas Andalas, Jl. Raya Unand, \\ Kampus Limau Manis, Padang, 25163, West Sumatera, Indonesia \\ ${ }^{2}$ Department of Social Economics, Faculty of Animal Husbandry, Universitas Andalas, Jl. Raya Unand, Kampus Limau Manis, \\ Padang, 25163, West Sumatera, Indonesia
}

\begin{abstract}
Article history
Received: 23-07-2021

Revised: 17-09-2021

Accepted: 29-09-2021

Corresponding Author:

Roni Pazla,

Department of Nutrition

Science and Feed Technology,

Faculty of Animal Husbandry, Universitas Andalas, Jl. Raya Unand, Kampus Limau Manis, Padang, 25163, West Sumatera, Indonesia

Email: ronipazla@ ansci.unand.ac.id
\end{abstract}

\begin{abstract}
This research aims to determine the optimal dosage of Phosphorus (P) and Sulfur (S) minerals for rumen microbial fermentative activity. The research method used an experimental method with a factorial randomized block design $(3 \times 3)$ with three repetitions for mineral $\mathrm{P}$ and S. P was the first factor with three dose levels, namely $\mathrm{Po}=0.0 \%$, $\mathrm{P} 1=0.27 \%$ and $\mathrm{P} 2=0.54$. The second factor is mineral $\mathrm{S}$ with 3 levels: $\mathrm{So}=0.0 \%, \mathrm{~S} 1=0.2 \%$ and $\mathrm{S} 2=0.4 \%$. The parameters measured were rumen fluid profile and nutrient digestibility. The results showed the interaction of $\mathrm{P}$ and $\mathrm{S}$ minerals on the APLF had no significant effect $(\mathrm{P}>0.05)$ on $\mathrm{pH}$, VFA and digestibility of hemicellulose but had a significant effect $(\mathrm{P}<0.05)$ on $\mathrm{NH}_{3}$, digestibility of dry matter, organic matter, crude protein, NDF, ADF and cellulose. In conclusion, the quality of ammoniated palm leaves and fronds can be improved by the addition of mineral dosage $\mathrm{P} 0.27 \mathrm{~S} 0.4 \%$.
\end{abstract}

Keywords: Ammoniation, In vitro, Mineral $\mathrm{P}$ and $\mathrm{S}$, Palm Leaves and Fronds, Rumen Fluid

\section{Introduction}

Dhamasraya is one of the districts of West Sumatra with an area of 2,961.13 km 2 (BPS, 2015). The area of oil palm plantations in Dharmasraya is around 32,309.60 hectares. Meanwhile, the area of rubber plantations reached 40,918.90 hectares (BPS, 2019). It can be said that $43 \%$ of the expanded area of Sijunjung Regency are rubber and oil palm plantations. In general, oil palm cultivation aims to obtain production in Fresh Fruit Bunches (FFB). By 2020, Indonesia has the vision to produce FFB 35/ha and a yield of $26 \%$. This vision certainly has a positive impact on the Indonesian economy, but it also leaves environmental problems in plantation waste (Rupani et al., 2010). One of the solid wastes that are very much produced from oil palm plantations is Palm Leaves and Fronds (PLF). Each oil palm tree produces 22 fronds per year or the equivalent of 20 thousand $\mathrm{kg}$ of fresh fronds per hectare per year (Diwyanto et al., 2008). The total available Dry Matter (DM) for fronds is 5,214 kg per hectare per year, with a DM content of $26.06 \%$. Each frond produces oil palm leaves weighing $0.5 \mathrm{~kg}$, so there is $658 \mathrm{~kg}$ of leaves per hectare per year (Mathius et al., 2017).

Various ideas emerged, all of which were aimed at reducing the impact of these wastes. Several studies have been carried out to utilize palm frond waste, namely as a base material for bioethanol (Ofori-Boateng and Lee, 2014, paper pulp Hussin et al., 2014), combustible gas with a gasification process (Guangul et al., 2014, composite panels Khalid et al., 2015 and compost Bulan, 2016).

Palm leaves and fronds can also be used as a source of forage for ruminants. In the Dhamasraya area, there are still few who use this garden waste as animal feed. Generally, farmers are more familiar with palm kernel cake as concentrate feed (Jamarun et al., 2020; Arief et al., 2020). Ruminants such as cows, buffaloes, goats and deer have advantages in their digestive organs that can digest low-quality forages such as PLF. The nutritional content of the PLF is $69.6 \%$ water content, $5.9 \%$ ash, 
$3.64 \%$ Crude Protein (CP), $49.80 \%$ Crude Fiber $(\mathrm{CF})$, $4.3 \%$ cellulose, $89.9 \%$ Neutral Detergent Fiber (NDF). Acid Detergent Fiber (ADF) 73.2\% and lignin 30.6\% (Pazla, 2018).

The main obstacle to the leaves and fronds is the presence of sticks on the leaves and woody substances on the fronds. Sticks and fronds are parts of oil palm, which contain high lignin. lignin is a wood substance that cannot be broken down by rumen microbes, causing low digestibility (Jamarun et al., 2018) maximum inclusion is carried out in the form of processing through feed technology to optimize PLF as animal feed, one of which is ammoniation. Ammoniation can loosen the lignocellulose and lignohemicellulose bonds that exist in plants and increase the CP content sourced from Urea (Suryani et al., 2016). Ammoniation techniques will be maximized when combined with the addition of minerals needed by rumen microbes such as $\mathrm{P}$ and $\mathrm{S}$. $\mathrm{P}$ and $\mathrm{S}$ minerals are macro minerals that are essential for rumen microbial growth and are often deficient in fibrous feeds that contain low nutritional value and bioavailability (Febrina et al., 2016a). The addition of $\mathrm{P}$ and $\mathrm{S}$ minerals to high fiber feed can optimize rumen bioprocessing so that the digestibility of the feed material which was initially low can increase (Suyitman et al., 2020). this increase in digestibility value is through optimal growth of rumen microbes so that the population increases and of course, will produce enough fiber digesting enzymes to break down complex substances into simple ones. The purpose of this study was to utilize the potential waste from oil palm plantations from Dhamasraya, West Sumatra as an alternative feed for ruminants, increase the nutrient value and digestibility of PLF waste and determine the optimal dosage of $\mathrm{P}$ and $\mathrm{S}$ minerals through in vitro tests in the laboratory. The results of this study can be useful as a reference, information and recommendations for the creation of palm oil waste-based feed formulas and technological innovations for the community and breeders in providing quality, easy to obtain, economical and sustainable feed every year to support the productivity of ruminants, especially beef cattle.

\section{Materials and Methods}

\section{Study Area}

Ammoniation of PLF is carried out at the Cerdas Farmers Group's oil palm plantations: Tiumang, Dharmasraya District, West Sumatra, Indonesia. Chemical composition analysis, in vitro test, $\mathrm{pH}$, VFA and $\mathrm{NH}_{3}$ measurements were carried out at the ruminant nutrition laboratory, Animal Husbandry Faculty and alas University, Padang, West Sumatera, Indonesia.

\section{Preparation of Tools and Materials}

The materials needed in this research are PLF, Urea fertilizer, mineral $\mathrm{P}$ from SP-36 fertilizer, mineral $\mathrm{S}$ from sulfur, rumen fluid, $\mathrm{McD}$ ougall solution, saturated $\mathrm{HgCl}_{2}$ solution, $\mathrm{CO}_{2}$ gas, BHI media (Brain Heart Infusion). Materials for the volatile fatty acids (VFA) test include $0.5 \mathrm{~N} \mathrm{NaOH}$ solution, $0.5 \mathrm{~N} \mathrm{HCl}$ solution, $15 \% \mathrm{H}_{2} \mathrm{SO}_{4}$, $1 \% \mathrm{NaCl}, 1 \% \mathrm{HCl}, 10 \% \mathrm{HCl}$ and minerals (Ca, P, Mg and $\mathrm{S}$ ). The materials used for the $\mathrm{NH}_{3}$ test include boric acid $\left(\mathrm{H}_{3} \mathrm{BO}_{3}\right)$, vaseline, Phenolphthalein indicator (PP), saturated $\mathrm{Na}_{2} \mathrm{CO}_{3}, \mathrm{H}_{2} \mathrm{SO}_{4} 0.005 \mathrm{~N}$ and $\mathrm{Na}_{2} \mathrm{SO}_{4}$. The equipment used for rumen $\mathrm{pH}$ measurement is a $\mathrm{pH}$ meter measuring device, chemical equipment for proximate and van Soest analysis and in vitro testing equipment.

\section{Ammoniation and in vitro Procedure}

The method used in this study's ammoniation process is wet ammoniation using urea as a source of $\mathrm{NH}_{3}$. Urea is weighed by an amount of $5 \%$ of the weight of the PLF (Zain, 2009; Suyitman et al., 2020). The amount of water needed to dissolve urea has a 1:1 with the dry matter of PLF. Then it is dissolved into water. The PLF that have been in the chopper are put in a plastic bag that has been lined with two plastic sheets so that they do not leak quickly and then the urea solution is splashed and mixed gradually on the PLF in the plastic bag. Then stir and turn a little until evenly distributed throughout. Then the PLF in the plastic is compacted. Then closed and tied at the top so that the condition becomes anaerobic. After 21 days of ammoniation, the PLF was opened. Then it was aerated and then milled (size 40 mash) for chemical composition analysis and samples in the in vitro test.

The in vitro test followed Tilley and Terry's (1963) procedure. Nutrient analysis followed the procedure of the AOAC (2005). Fiber fraction analysis followed Van Soest et al. (1991). The $\mathrm{pH}$ value is measured using a $\mathrm{pH}$ meter. The concentration of $\mathrm{NH}_{3}$ and total VFA analysis as described in Putri et al. (2021). Chemical composition of PLF before and after ammonization can be seen in Table 1.

Table 1: Chemical composition of PLF before and after ammoniation

\begin{tabular}{lll}
\hline Parameters & Treatments & \\
$(\%)$ & A & B \\
\hline Dry matter & $54.12 \pm 0.02$ & $40.51 \pm 0.22$ \\
Organic matter & $89.86 \pm 0.11$ & $84.25 \pm 0.24$ \\
Ash & $10.14 \pm 0.11$ & $15.75 \pm 0.24$ \\
Crude protein & $8.51 \pm 0.06$ & $13.76 \pm 0.13$ \\
Crude Fiber & $28.48 \pm 0.05$ & $25.03 \pm 0.09$ \\
NDF & $59.11 \pm 0.03$ & $54.76 \pm 0.15$ \\
ADF & $45.64 \pm 0.06$ & $42.54 \pm 0.13$ \\
Cellulose & $24.69 \pm 0.09$ & $20.77 \pm 0.04$ \\
Hemicellulose & $13.47 \pm 0.05$ & $12.22 \pm 0.19$ \\
Lignin & $14.21 \pm 0.02$ & $10.74 \pm 0.20$ \\
\hline Note: A (Chemical composition of PLF before ammoniation)
\end{tabular}

$\mathrm{B}$ (Chemical composition of PLF after ammoniation) 


\section{Data Analysis}

The method used in this research is experimental method using a factorial Randomized Block Design ( $3 \times 3$ ) with three replications for dose $\mathrm{P}$ and $\mathrm{S}$. As the first factor is the treatment of mineral $\mathrm{S}$ with three levels: $\mathrm{S}_{0}=0 \%, \mathrm{~S}_{1}=0.2 \%$ and $\mathrm{S}_{2}=0.4 \%$ of DM. The second factor is the mineral $\mathrm{P}$ in 3 levels, ie $\mathrm{P}_{\mathrm{o}}=0 \%, \mathrm{P}_{1}=0.27 \%$ and $\mathrm{P}_{2}=0.54 \%$ of DM. the data is processed with analyses of variance based on the formula Steel and Torrie (1960). Duncan's Multiple range tests were used if there were significant differences between treatments. Statistical significance was declared at $p<0.05$.

The parameters measured in this study were the chemical composition (DM, OM, ash, CP, CF, NDF, ADF, Cellulose, Hemicellulose and lignin), PLF before and after ammoniation, rumen fluid characteristics $(\mathrm{pH}$, $\mathrm{NH}_{3}$ and total VFA) and digestibility of DM, OM, CP, NDF, ADF, cellulose and hemicellulose.

\section{Results and Discussion}

\section{Rumen Fluid Characteristics}

Based on Table 2 below, it can be seen that the fermentation process that occurs in the rumen with the addition of $\mathrm{P}$ and $\mathrm{S}$ minerals with different doses of ammoniated PLF has been going well with indications of $\mathrm{pH}$ values in all treatments in the range of 6.58 to 6.87. This value is still within the normal range (6-7) for microbial growth, development and microbial activity (Church, 1988; Erdman, 1988; Jamarun et al., 2020; Riestanti et al., 2021; Jamarun et al., 2017a) reported that the optimal $\mathrm{pH}$ value for the digestibility of the fiber fraction from fermented PLF is 6.74-6.76. The $\mathrm{pH}$ value of fermented PLF supplemented with minerals $\mathrm{P}, \mathrm{Mg}$ and $\mathrm{S}$ is 6.80-6.88 (Febrina et al., 2016a). Palm fronds supplemented with $\mathrm{Ca}$ and $\mathrm{Mn}$ minerals have a $\mathrm{pH}$ value of 6.67-6.87 (Febrina et al., 2016b).

The analysis results showed that $\mathrm{S}$ and P's mineral addition with various levels of different doses and their interactions had no significant effect $(\mathrm{P}>0.05)$ on rumen fluid of $\mathrm{pH}$. This condition is caused by the use of artificial saliva as a buffer, which can still maintain the rumen condition's stability from the influence of fermentation activity. This statement follows Nurhaita et al. (2008) opinion stated that saliva acts as a buffer to maintain rumen stability. The resulting balance of $\mathrm{NH}_{3}$ and VFA concentrations was also a factor causing the treatment's $\mathrm{pH}$ value not significantly different. Pazla et al. (2018a) stated that the rumen's pH value is a balanced interaction between the buffer capacity with the alkalinity and acidity of fermentation products.

The energy source of ruminants comes from VFA, which is produced in the rumen fermentation process. The statistical analysis results showed that the addition of $\mathrm{P}$ and $\mathrm{s}$ minerals at different doses and their interaction did not significantly $(\mathrm{P}>0.05)$ affect the production of VFA concentrations. The concentration of VFA produced in the rumen fermentation process depends on the variety of carbohydrate sources in a feed ingredient (Nurhaita et al., 2008). The source of carbohydrates in this research was only one type, namely the PLF so that the total VFA produced did not show a significant difference $(\mathrm{P}>0.05)$. The range of VFA production obtained in this study was 97.17 to 118.59 $\mathrm{mM}$. This value is sufficient to support the optimal growth of rumen microbial. Waldron et al. (2002) stated that VFA concentrations ranged from $60-120 \mathrm{mM}$.

$\mathrm{NH}_{3}$ is the primary nitrogen source and vital for the activity and growth of rumen microbes. The statistical analysis results for the effect of treatment on rumen fluid $\mathrm{NH}_{3}$ levels showed that the addition of $\mathrm{p}$ and $\mathrm{s}$ minerals and their interaction had a significant effect $(\mathrm{P}<0.05)$ on $\mathrm{NH}_{3}$ levels in rumen fluid. The addition of $\mathrm{P}$ and $\mathrm{S}$ minerals to fermented palm fronds also had a significantly different effect on the $\mathrm{NH}_{3}$ (Febrina, 2016a). The highest $\mathrm{NH}_{3}$ value was obtained in treatment P0S2 and the lowest was in treatment P1S0. These results indicate that the concentration of $\mathrm{NH}_{3}$ in the rumen fluid is more dominantly influenced by $\mathrm{S}$ than $\mathrm{P}$. According to the research results of Nurhaita et al., (2008), S minerals show a more prominent effect compared to mineral $\mathrm{P}$ in producing $\mathrm{NH}_{3}$ in rumen fluid. The range of $\mathrm{NH}_{3}$ levels in rumen fluid obtained in this study was $52.57-62.56 \mathrm{mg} / 100 \mathrm{~mL}$. This value has met the needs of $\mathrm{NH}_{3}$ for microbes to be able to digest feed optimally, which is 50-200 $\mathrm{mg} / 100 \mathrm{~mL}$ (Paengkoum et al., 2006). $\mathrm{NH}_{3}$ concentrations at the minimum limit can interfere with the fermentation process (Rutemor et al., 2008). The minimum limit of $\mathrm{NH}_{3}$ concentration in the rumen fluid is $3.6 \mathrm{mM}$ or the equivalent of $50 \mathrm{mg} / 100 \mathrm{~mL}$.

\section{Nutrient Digestibility}

The effect of adding mineral $\mathrm{P}$ and $\mathrm{S}$ doses on APLF is presented in Table 3. There is a significant interaction effect $(\mathrm{P}>0.05)$ between mineral $\mathrm{P}$ and $\mathrm{S}$ dose levels on nutrient digestibility (DM, OM and CP) of APLF. The digestibility of DM, OM and CP from APLF added with several levels of mineral $\mathrm{P}$ and $\mathrm{S}$ doses were significantly increased compared to control P0S0. This increase proves that the addition of $\mathrm{P}$ and $\mathrm{S}$ minerals in feed can increase the growth and population of rumen microbes to maximize digestive enzymes to degrade high fiber feedstuffs, increasing the digestibility value of feed ingredients. Digestibility in S2P1 treatment showed the highest value, namely the addition of mineral doses of $0.27 \% \mathrm{P}$ and $0.4 \% \mathrm{~S}$ from DM, namely 46.43, 55.78 and $54.81 \%$, respectively for digestibility of DM, OM and CP. There was an increase in DM, OM and CP's digestibility values in this treatment, respectively, 37.82, 23.97 and $19.23 \%$ compared to the control POSO. The dosage combination in $\mathrm{S} 2 \mathrm{P} 1$ treatment showed the 
optimal combination of $\mathrm{P}$ and $\mathrm{S}$ minerals because it increased the digestibility value. This dosage is due to the ability of minerals to stimulate the growth and activity of rumen microbes. The control SOP0 treatment showed the lowest digestibility values of food substances of 33.69 , 42.41 and $45.97 \%$, respectively, for the digestibility of DM, $\mathrm{OM}$ and $\mathrm{CP}$. This treatment's low digestibility value was due to the absence of additional mineral $\mathrm{P}$ and $\mathrm{S}$ supplementation. Mineral $\mathrm{P}$ and $\mathrm{S}$ are essential minerals to stimulate rumen microbial growth. Genther and Hansen (2014) stated that rumen microbes need mineral supplementation to fulfill their normal function to stimulate proliferation and fermentation activity. Mineral P is a mineral needed for ATP synthesis and microbial protein synthesis (Karsli and Russell, 2001; Febrina et al, 2020; Pazla et al., 2018a).

The addition of mineral $\mathrm{P}$ to fermented PLF can improve nutritional quality, thereby increasing digestibility (Febrina et al., 2016a; Pazla et al., 2020). The addition of P 0.4 and S $0.3 \%$ minerals can improve the digestibility of DM, OM and CP from ammoniated cocoa leaves and pods (Pazla et al., 2018b). Bal and Ozturk (2006) stated that rumen microbes need mineral S as a material for forming sulfur-containing amino acids. The concentration of VFA increases in rice straw ammoniation supplemented with $\mathrm{S}$ minerals compared without ammoniation (Zain et al., 2010a). The addition of the mineral $\mathrm{S}$ as sulfur and thiosulfate in sheep was also able to increase the rumen fluid's VFA levels (Grace et al., 1997). Increased VFA concentrations positively correlate with the digestibility of OM (Dias et al., 2006; and Karcher et al., 2007; Sartono et al., 2007).

Increasing the Dose of Mineral S from 0\% (POSO) to $0.4 \%$ (P0S2) was significant $(\mathrm{P}<0.05)$, Increasing the digestibility value of the DM, OM and CP. The optimum combination of mineral $\mathrm{S}$ and $\mathrm{P}$ doses to increase nutrient digestibility was obtained in the P1S2 treatment; namely, 0.27 P and 0.4\% S. Pazla et al., (2018a) said that if the needs of rumen microbes are met to develop and create a conducive rumen condition, the microbial population will be optimal. It was thus accelerating the rate of degradation of feed components, which in turn increases nutrient digestibility. An increase in the P dose from 0.27 to $0.54 \%$ decreased the digestibility value of DM, OM and CP. The decreased value of nutrient digestibility at a dose of $\mathrm{P} 0.54 \%$ was due to the optimum rumen microbes using a $0.27 \%$ dose of mineral $\mathrm{P}$ for growth and activity so that the $0.54 \% \mathrm{P}$ mineral dose had begun to interfere with the performance of rumen microbes in degrading feed, even though it had not caused any harmful toxic effects. This condition is indicated by the standard $\mathrm{pH}, \mathrm{VFA}$ and $\mathrm{NH}_{3}$ values of all treatments.

\section{Fiber Fraction Digestibility}

Table 4 shows that the POS0 treatment (without minerals) produced the lowest digestibility values for
NDF, ADF, Cellulose and Hemicellulose compared to other treatments. The low digestibility is due to the inadequate role of rumen microbes in degrading feed. The addition of mineral $\mathrm{P}$ and $\mathrm{S}$ doses significantly $(\mathrm{P}>0.05)$ increased the digestibility value of NDF, ADF and Cellulose. The increase in digestibility in this treatment compared to the control (P0S0) shows that $\mathrm{P}$ mineral plays a role in the metabolic processes and cell wall digestibility carried out by rumen microbes. Karsli and Russell (2001) stated that mineral $\mathrm{P}$ is needed by all microbial cells to maintain cell membranes and the integrity of cell walls. Pazla et al. (2018b) stated that mineral P is needed to degrade the cell wall fraction of feed ingredients by cellulolytic bacteria. $\mathrm{P}$ supplementation in fermented palm fronds in vitro can increase the digestibility of NDF, ADF and cellulose (Jamarun et al., 2017b). Zain et al. (2010b) added that mineral $\mathrm{P}$ supplementation increased the digestibility of NDF, ADF and cellulose from ammoniated rice straw. Mineral $\mathrm{S}$ is indispensable for the degradation of crude fiber in the rumen to stimulate cellulolytic bacteria (Bal and Ozturk, 2006). The addition of Mineral $S$ to ammoniated rice straw can improve cellulose digestibility (Zain et al., 2010a).

There is an interaction of $\mathrm{P}$ and $\mathrm{S}$ minerals on NDF, ADF and cellulose's digestibility. Table 4 shows the highest dose combination of $\mathrm{P}$ and $\mathrm{S}$ minerals in increasing the digestibility of NDF and ADF found in the $\mathrm{P} 1 \mathrm{~S} 2$ treatment, namely the addition of the mineral dosage $\mathrm{P} 0.27$ and $\mathrm{S} 0.4 \%$. The highest cellulose digestibility was achieved in the P1S1 combination, namely the addition of a dose of P 0.27 and $\mathrm{S} 0.2 \%$, but it was not significantly different $(\mathrm{P}>0.05)$ with $\mathrm{P} 1 \mathrm{~S} 2$. In contrast, the hemicellulose digestibility did not show a significant difference $(\mathrm{P}>0.05)$ in all treatments. The high digestibility of fiber fractions in the P1S2 treatment was due to the optimum dose combination of $\mathrm{P}$ and $\mathrm{S}$ minerals for rumen microbes' growth and activity, especially cellulolytic bacteria in degrading feed. Suyitman et al (2015) stated that the increase in population and cellulolytic microbial activity would increase the digestibility of NDF, ADF and cellulose. Mineral P is an essential mineral to support microbial growth, especially fiber digesting microbes (Soetan et al., 2010). Mineral P at normal levels in the rumen can increase rumen microbial activity in digesting fiber (Febrina et al., 2016a). Rumen microbes need mineral $\mathrm{S}$ to form amino acids (Bal and Ozturk, 2006). P and S minerals' addition causes PLF to be more fermentable in the rumen and rumen microbes can grow and do activities optimally to degrade the fraction of feed fiber and improve digestibility. Nurhaita et al. (2008) reported that $\mathrm{P}$ and $\mathrm{S}$ minerals' addition to ammoniated palm leaves in sheep rations increased the fiber fraction. Suyitman et al. (2020) and Zain et al. (2010c) reported an increase in the fiber fraction's digestibility in beef cattle rations supplemented with $\mathrm{P}$ and $\mathrm{S}$ minerals. 
Tabel 2: Effect of supplementation of mineral $\mathrm{S}$ and $\mathrm{P}$ on ammoniated palm leaves and fronds on the characteristic of rumen fluid.

\begin{tabular}{|c|c|c|c|c|c|c|}
\hline \multirow{3}{*}{$\begin{array}{l}\text { Chara. of } \\
\text { Rumen } \\
\text { Fluid } \\
\end{array}$} & \multicolumn{6}{|c|}{ Treatments } \\
\hline & \multicolumn{6}{|l|}{$\mathrm{P}$} \\
\hline & $\mathrm{S}$ & $\mathrm{P} 0$ & $\mathrm{P} 1$ & $\mathrm{P} 2$ & Av. & S.E. \\
\hline \multirow[t]{3}{*}{$\mathrm{pH}$} & $\mathrm{S} 1$ & $6.87 \pm 0.72$ & $6.83 \pm 0.03$ & $6.83 \pm 0.10$ & 6.84 & 0.08 \\
\hline & $\mathrm{S} 2$ & $6.67 \pm 1.07$ & $6.85 \pm 0.09$ & $6.65 \pm 1.03$ & 6.72 & \\
\hline & Av. & 6.72 & 6.75 & 6.71 & & \\
\hline \multirow[t]{3}{*}{ VFA $(\mathrm{mM})$} & $\mathrm{S} 1$ & $97.17 \pm 1.52$ & $103.16 \pm 1.77$ & $105.37 \pm 2.87$ & 101.90 & 5.37 \\
\hline & $\mathrm{S} 2$ & $105.59 \pm 3.73$ & $107.85 \pm 2.86$ & $106.51 \pm 0.33$ & 106.65 & \\
\hline & Av. & 107.12 & 107.99 & 106.93 & & \\
\hline \multicolumn{7}{|c|}{$\mathrm{NH}_{3}(\mathrm{mg} / 100 \mathrm{~mL})$} \\
\hline & So & $55.83^{\mathrm{Aba}} \pm 1.89$ & $52.57^{\mathrm{Ba}} \pm 2.59$ & $61.81^{\mathrm{Aa}} \pm 2.32$ & 56.71 & \\
\hline & $\mathrm{S} 1$ & $57.94^{\mathrm{Aa}} \pm 0.98$ & $57.90^{\mathrm{Aa}} \pm 0.82$ & $56.84^{\mathrm{Aab}} \pm 1.45$ & 57.56 & 2.69 \\
\hline & $\mathrm{S} 2$ & $62.56^{\mathrm{Aa}} \pm 0.83$ & $58.71^{\mathrm{Aba}} \pm 0.92$ & $51.57^{\mathrm{Bb}} \pm 1.66$ & 57.61 & \\
\hline
\end{tabular}

Values with different superscripts in the row (capital letters) and columns (lower case) are significantly $(\mathrm{p}<0.05)$

Av: Average, Chara: Characteristic

Table 3: Effect of mineral S and P supplementation on nutrient digestibility of ammoniated palm leaf and fronds (\%).

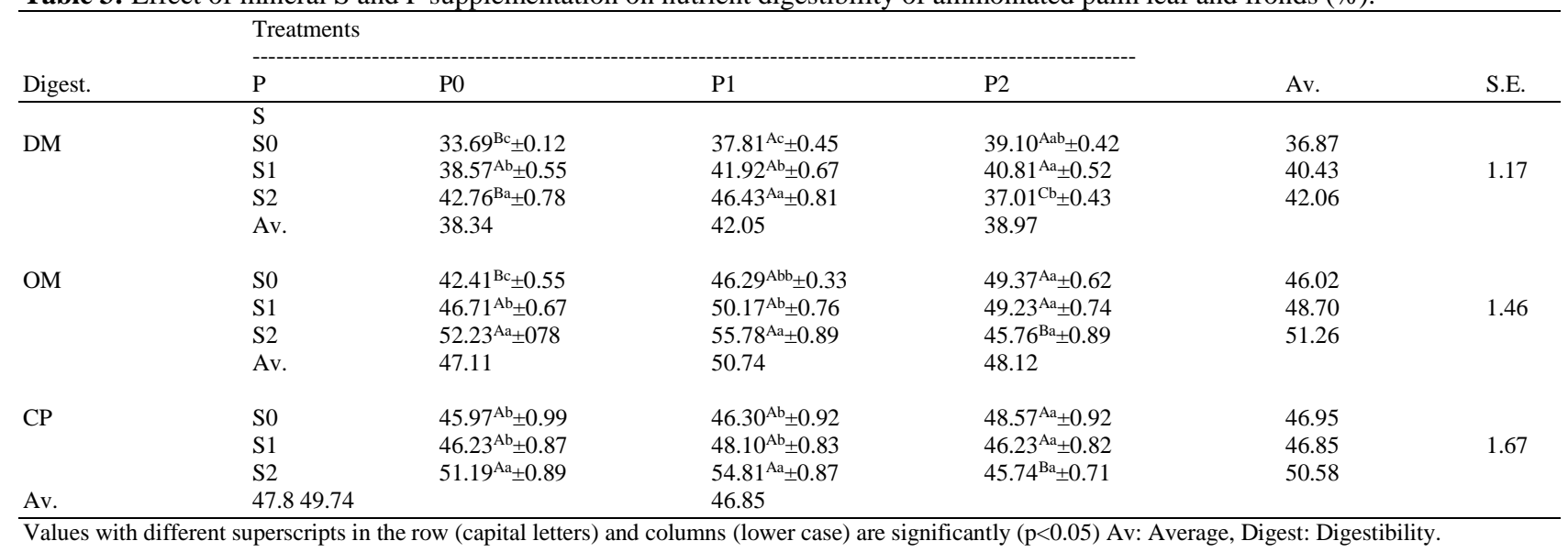

Table 4: Effect of S and P mineral supplementation on digestibility of fiber fractions of ammoniated palm leaves and fronds.

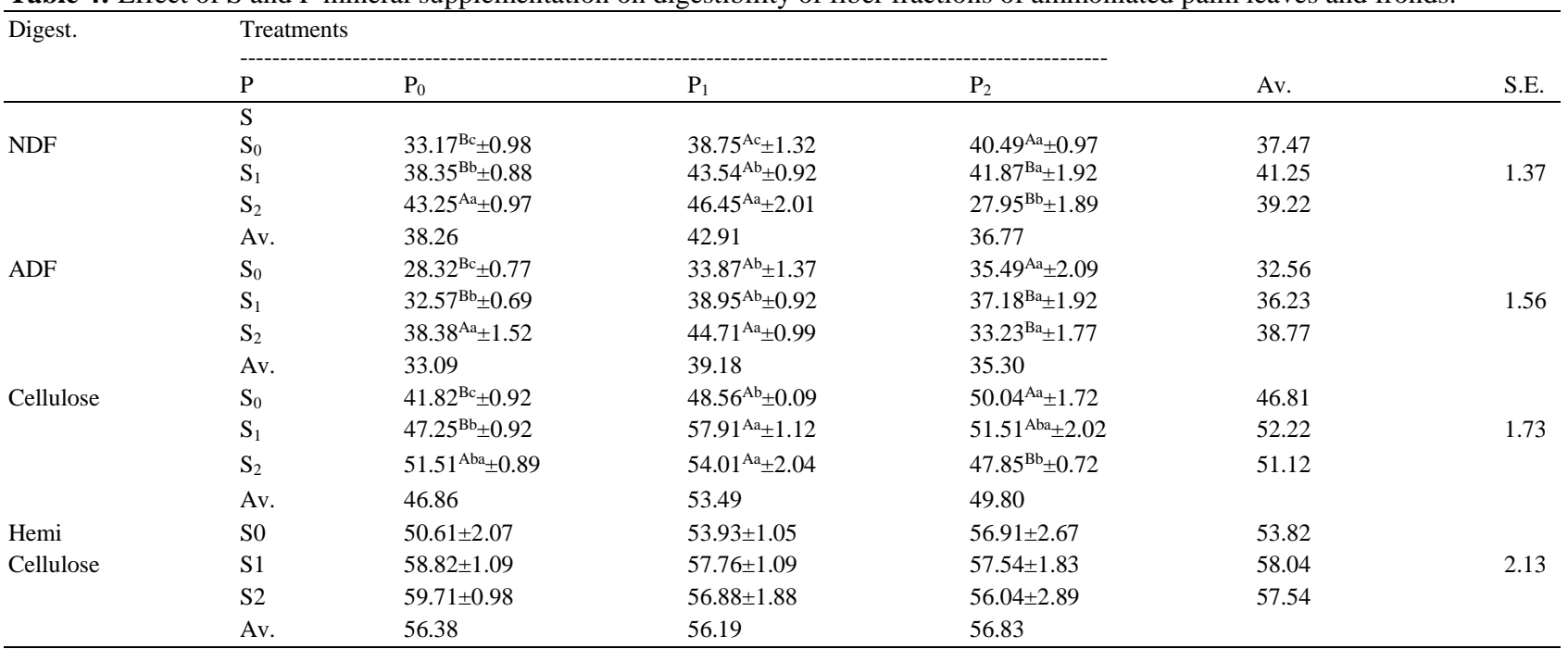

Values with different superscripts in the row (capital letters) and columns (lower case) are significantly $(\mathrm{p}<0.05)$

Av: Average, Digest: Digestibility 


\section{Conclusion}

This research concludes that APLF can improve nutritional quality. The addition of P $0.27 \%$ and S $0.4 \%$ mineral dosages in APLF can improve nutrient digestibility and fiber fraction without disturbing fermentative activity, which is reflected in standard $\mathrm{pH}$ value, NH3 and VFA.

\section{Acknowledgment}

Thanks to Andalas University and the Research Directorate and Service Community, the DirectorateGeneral for Research and Development and the Ministry of Research, Technology and Higher Education, who funded this research. This researchbased contract No. 163/SP2H/AMD/LT/ DRPM/2020, the fiscal year 2020 .

\section{Author's Contributions}

Suyitman: Participated in all experiments, analyzed, interpreted data and wrote the manuscript.

Lili Warly: Designed, supervised the laboratory and interpreted the data.

James Hellyward: Designed, supervised the experiment work and proofread the manuscript.

Roni Pazla: In vitro test and wrote the manuscript.

\section{Ethics}

This research and article are original and contains unpublished material before. The corresponding author confirms that all of the authors have read and approved the article and no ethical issues are involved.

\section{References}

AOAC. (2005). International A: Official Methods of Analysis of the AOAC International. The Association: Maryland County, VA, USA.

Jamarun, N., Pazla, R., Zain, M., \& Arief. (2020, February). Milk quality of Etawa crossbred dairy goat fed combination of fermented oil palm fronds, Tithonia (Tithonia diversifolia) and Elephant Grass (Pennisetum Purpureum). In Journal of Physics: Conference Series (Vol. 1469, No. 1, p. 012004). IOP Publishing.

https://iopscience.iop.org/article/10.1088/17426596/1469/1/012004/meta

Arief, A., Rusdimansyah, R., Sowmen, S., Pazla, R., \& Rizqan. (2020). Milk production and quality of Etawa crossbreed dairy goat that given Tithonia diversifolia, corn waste and concentrate based palm kernel cake. Biodiversitas Journal of Biological Diversity, 21(9). doi.org/10.13057/biodiv/d210910
Bal, M. A., \& Ozturk, D. (2006). Effects of sulfur containing supplements on ruminal fermentation and microbial protein synthesis. Res. J. Anim. and Vet. Sci, 1, 33-36. http://www.aensiweb.net/AENSIWEB/rjavs/rjavs/2 006/33-36.pdf

Ofori-Boateng, C., \& Lee, K. T. (2014). Ultrasonicassisted simultaneous saccharification and fermentation of pretreated oil palm fronds for sustainable bioethanol production. Fuel, 119, 285-291. doi.org/10.1016/j.fuel.2013.11.064

BPS. 2015. Statistik Kelapa Sawit Indonesia (Indonesian Oil Palm Statistics) 2015. BPS Indonesia, Jakarta. ISBN-10: 1978-9947.

BPS. 2019. Statistik Perkebunan Indonesia 2019. BPS Indonesia, Jakarta. ISBN: 1978-9947.

Bulan, R. (2016) Pengembangan Sistem Mekanisasi Pemanfaatan Pelepah Kelapa Sawit Untuk Mulsa Dan Kompos (Doctoral dissertation, IPB (Bogor Agricultural University)).

https://repository.ipb.ac.id/handle/123456789/83521

Church, D. C. (1988). The Ruminant animal: digestive physiology and nutrition. https://agris.fao.org/agrissearch/search.do?recordID=US19890092792

Dias, R. S., Kebreab, E., Vitti, D. M. S. S., Roque, A. P., Bueno, I. C. S., \& France, J. (2006). A revised model for studying phosphorus and calcium kinetics in growing sheep. Journal of Animal Science, 84(10), 2787-2794. doi.org/10.2527/jas.2006-082

Diwyanto, K., D. Priyanti, A., \& Saptanti, R.A. (2008). Proyek pengembangan usaha peternakan pola integrasi. Journal of Sustainable Agriculture, 23(2), 119-132. https://jurnal.uns.ac.id/carakatani/article/view/13996 $/ 11638$

Erdman, R. A. (1988). Dietary buffering requirements of the lactating dairy cow: a review. Journal of Dairy Science, 71(12), 3246-3266. doi.org/10.3168/jds. S0022-0302(88)79930-0

Febrina, D., Jamarun, N., Zain, N., \& Khasrad. (2016a). The effects of $\mathrm{P}, \mathrm{S}$ and $\mathrm{Mg}$ supplementation of oil palm fronds fermented by Phanerochayte chrysosporium on Rumen Fluid Characteristics and Microbial Protein Synthesis. Pakistan Journal of Nutrition 15(3), 299-304. doi.org/10.3923/pjn.2016.299.304

Febrina, D., Jamarun, N., \& Zain, M. (2016b). Effects of Calcium (Ca) and Manganese (Mn) Supplementation During Oil Palm Frond Fermentation by Phanerochaete chrysosporium on in Vitro Digestibility and Rumen Fluid Characteristics (Hasil Check Similarity). Pakistan Journal of Nutrition, 15(4), 352-358.

http://repository.uinsuska.ac.id/26543/1/Artike1\%207.pdf 
Febrina, D., Jamarun, N., \& Zain, M. (2020). Effects of Using Different Levels of Oil Palm Fronds (POPFS) Fermented with Phanerochaete chrysosporium Plus Minerals (P, S and Mg) Instead of Napier Grass on Nutrient Comsumption and the Growth Performance of Goats (Hasil Check Similarity).

http://repository.uinsuska.ac.id/26519/1/artikel\%206.pdf

Genther, O. N., \& Hansen, S. L. (2014). Effect of dietary trace mineral supplementation and a multi-element trace mineral injection on shipping response and growth performance of beef cattle. Journal of animal science, 92(6), 2522-2530. doi.org/10.2527/jas.2013-7426

Grace, N. D., Rounce, J. R., Knowles, S. O., \& Lee, J. (1997). Changing dietary $\mathrm{S}$ intakes and the $\mathrm{Cu}$ status of grazing lambs. New Zealand journal of agricultural research, 40(3), 329-334. doi.org/10.1080/00288233.1997.9513252

Guangul, F.M., Sulaiman., S.A., \& Ramli, A.. (2014). Study the effects of operating factors on the resulting producer gas of oil palm fronds gasification with a single throat downdraft gasifier. J. Renewable Energy. 72: 271-283. doi.org/10.1016/j.renene.2014.07.022

Hussin, M. H., Rahim, A. A., Ibrahim, M. N. M., Perrin, D., Yemloul, M., \& Brosse, N. (2014). Impact of catalytic oil palm fronds (OPF) pulping on organosolv lignin properties. Polymer degradation and stability, 109, 33-39. https://www.sciencedirect.com/science/article/pii/S 0141391014002535

Jamarun, N., Zain, M., Arief., \& Pazla, R. (2017a). Effects of calcium, phosphorus and manganese supplementation during oil palm frond fermentation by Phanerochaete chrysosporium on laccase activity and in vitro digestibility. Pak J Nutr,16(3),119-124. http://dx.doi.org/10.3923/pjn.2017.119.124

Jamarun, N., Zain, M., Arief., \& Pazla, R. (2017b). Effects of calcium (Ca), phosphorus (P) and manganese $(\mathrm{Mn})$ supplementation during oil palm frond fermentation by Phanerochaete chrysosporium on rumen fluid characteristics and microbial protein synthsis. Pak J Nutr, 16(6), 39399. http://dx.doi.org/10.3923/pjn.2017.393.399

Jamarun, N., Zein, M., \& Arief, P. R. (2018). Populations of rumen microbes and the in vitro digestibility of fermented oil palm fronds in combination with Tithonia (Tithonia diversifolia) and elephant grass (Pennisetum purpureum). Pak J Nutr, 17(1), 39-45. doi.org/10.3923/pjn.2018.462.470

Jamarun, N., Pazla, R., Arief, A., Jayanegara, A., \& Yanti, G. (2020). Chemical composition and rumen fermentation profile of mangrove leaves (Avicennia marina) from West Sumatra, Indonesia. Biodiversitas Journal of Biological Diversity, 21(11). doi.org/10.13057/biodiv/d211126
Karcher, E. L., Pickett, M. M., Varga, G. A., \& Donkin, S. S. (2007). Effect of dietary carbohydrate and monensin on expression of gluconeogenic enzymes in liver of transition dairy cows. Journal of animal science, 85(3), 690-699. doi.org/10.2527/jas.2006-369

karsli, M. A., \& Russell, J. R. (2001). Effects of some dietary factors on ruminal microbial protein synthesis. Turkish Journal of Veterinary and Animal Sciences, 25(5), 681-686.

https://journals.tubitak.gov.tr/veterinary/abstract.ht $\mathrm{m} ? \mathrm{id}=4968$

Khalid, I., Sulaiman, O., Hashim, R., Razak, W., Jumhuri, N., \& Rasat, M. S. M. (2015). Evaluation on layering effects and adhesive rates of laminated compressed composite panels made from oil palm (Elaeis guineensis) fronds. Materials \& Design, 68, 24-28. https://www.sciencedirect.com/science/article/abs/pi i/S0261306914009893

Mathius, I. W., Bahri, S., \& Subandriyo. (2017). Akselerasi Pengembangan Sapi Potong Melalui Sistem Integrasi tanaman Ternak: sawit-Sapi. PT Penerbit IPB Press, Bogor. ISBN: 978-602-440250-1.

Nurhaita, N., Jamarun, N., Saladin, R., Warly, L., \& Mardiati, Z. (2008). The Effect of Sulphur and Phosphorus Supplementation at Ammoniation of Palm Oil Leaves on In Vitro Digestibility and Rumen Liquid Characteristics. Journal of the Indonesian Tropical Animal Agriculture, 33(1), 51-58. http://eprints.undip.ac.id/18670/

Paengkoum, P., Liang, J. B., Jelan, Z. A., \& Basery, M. (2006). Utilization of steam-treated oil palm fronds in growing saanen goats: II. Supplementation with energy and urea. Asian-australasian journal of animal sciences, 19(11), 1623-1631. doi.org/10.5713/ajas.2006.1623

Pazla, R., N. Jamarun., F. Agustin., M, Zain., Arief., \& N.O. Cahyani. (2020). Effects of supplementation with phosphorus, calcium and manganese during oil palm frond fermentation by phanerochaete chrysosporium on ligninase enzyme activity. Biodiversitas 21(5): 1833-38. https://doi.org/10.13057/biodiv/d210509

Pazla, R., Jamarun, N., Zain, M., \& Arief, A. (2018a). Microbial protein synthesis and in vitro fermentability of fermented oil palm fronds by Phanerochaete chrysosporium in combination with Tithonia (Tithonia diversifolia) and elephant grass (Pennisetum purpureum). Pak. J. Nutr, 17(10), 462-470. https://scialert.net/abstract/?doi=pjn.2018.462.470

Pazla, R., Zain, M., Ryanto, H. I., \& Dona, A. (2018b). Supplementation of minerals (phosphorus and sulfur) and Saccharomyces cerevisiae in a sheep diet based on a cocoa by-product. Pakistan Journal of Nutrition, 17(7), 329-335.

https://scialert.net/abstract/?doi=pjn.2018.329.33 
Pazla, R. (2018). Pemanfaatan Pelepah Sawit dan Titonia (I) Dalam Ransum Kambing Peranakan Etawa Untuk Menunjang Program Swasembada Susu 2020 (Doctoral dissertation, Universitas Andalas). http://scholar.unand.ac.id/40170/

Putri, E.M., Zain, M., Warly, L., \& Hermon, H. (2021). Effects of rumen-degradable-to-undegradable protein ratio in ruminant diet on in vitro digestibility, rumen fermentation and microbial protein synthesis. Vet. World. 14(3): 640-648. doi.org/10.14202/VETWORLD.2021.640-648

Riestanti, L.U., Despal., \& Retnani, Y. (2021). Supplementation of prill fat derived from palm oil on nutrient digestibility and dairy cow performance. American Journal of Animal and Veterinary Sciences, 16(2): 172-184. doi.org/10.3844/ajavsp.2021.172.184

Rupani, P. F., Singh, R. P., Ibrahim, M. H., \& Esa, N. (2010). Review of current palm oil mill effluent (POME) treatment methods: Vermicomposting as a sustainable practice. World Applied Sciences Journal, 11(1), 70-81.

https://d1wqtxts1 xzle7.cloudfront.net/30492048/12with-cover-page-

Rutemor, S.D., Jacha. J., Widjajakusuma, R., Permana, L.G. \& Sutama, I.K. (2008). Suplementasi daun bangunbangun (Coleus amboinicus Lour) dan zinc vitamin E untuk memperbaiki metabolisme dan produksi susu kambing Peranakan Etawa. JITV 13(3), 174-181.

Sartono., T.A., Nurwanto., \& J. Achmadi. (2007). Fermentabilitas mikrobia rumen secara in vitro terhadap onggok yang difermentasikan dengan campuran ragi. Prosiding seminar nasional AINI VI. pp, 350-355.

Soetan, K. O., Olaiya, C. O., \& Oyewole, O. E. (2010). The importance of mineral elements for humans, domestic animals and plants-A review. African journal of food science, 4(5), 200-222. doi.org/10.5897/AJFS.9000287

Steel, R. G. D., \& Torrie, J. H. (1960). Principles and procedures of statistics. Principles and procedures of statistics.

https://www.cabdirect.org/cabdirect/abstract/196116 01129

Suryani, H., Zain, M., Ningrat, R. W. S., \& Jamarun, N. (2016). Supplementation of Direct Fed Microbial (DFM) on in vitro Fermentability and degradability of ammoniated palm frond. Pakistan Journal of Nutrition, 15(1), 90.

Suyitman, Warly. L., Rachmat, A., \& Ramadhan, D. R. (2015). Effect of minerals S, P and cassava flour leaf supplemented with ammoniation palm leaves on the performance of beef cattle. Pakistan J. Nutr, 14(12):849-853.

https://dx.doi.org/10.3923/pjn.2015.849.853
Suyitman, W. L., Rahmat, A., \& Pazla, R. (2020). Digestibility and performance of beef cattle fed ammoniated palm leaves and fronds supplemented with minerals, cassava leaf meal and their combinations. Adv. Anim. Vet. Sci, 8(9), 991-996. doi.org/10.17582/journal.aavs/2020/8.9.991.996

Tilley, J. M. A., \& Terry, D. R. (1963). A two - stage technique for the in vitro digestion of forage crops. Grass and forage science, 18(2), 104-111. doi.org/10.1111/j.1365-2494.1963.tb00335.x

Van Soest, P. J., Robertson, J. B., \& Lewis, B. A. (1991). Methods for dietary fiber, neutral detergent fiber and nonstarch polysaccharides to animal nutrition. Journal of Dairy Science 74(10), 358397. doi.org/10.3168/jds.S0022-0302(91)78551-2

Waldron, M. R., Schrick, F. N., Quigley, J. D., Klotz, J. L., Saxton, A. M., \& Heitmann, R. N. (2002). Volatile fatty acid metabolism by epithelial cells isolated from different areas of the ewe rumen. Journal of animal science, 80(1), 270-278. doi.org/10.2527/2002.801270x

Zain, M. (2009). Substitution of native grass with ammoniated cocoa pod in sheep diet. https://repository.ipb.ac.id/handle/123456789/43197

Zain, M., \& Jamarun, N. (2010a). Effect of sulfur supplementation on in vitro fermentability and degradability of ammoniated rice straw. Pakistan Journal of Nutrition, 9(5), 413-415. https://www.cabdirect.org/cabdirect/abstract/201031 52367

Zain, M., Jamarun, N., \& Tjakradidjaja, A. S. (2010b). Phosphorus supplementation of ammoniated rice straw on rumen fermentability, synthesised microbial protein and degradability in vitro. World Acad. Sci. Eng. Technol, 4, 357-359.

http://citeseerx.ist.psu.edu/viewdoc/download?doi=1 0.1.1.294.3338\&rep=rep1\&type $=$ pdf

Zain, M., \& Jamarun, N. (2010c). Effect of phosphorus and sulphur supplementation in growing beef cattle diet based on rice straw ammoniated. Asian Journal of Scientific Research, 3(3), 184-188.

https://www.cabdirect.org/cabdirect/abstract/201032 02431 